\title{
ACOUSTICAL TENSOR AND ELASTIC WAVE PROPAGATION IN ANISOTROPIC MATERIALS USED IN AUTOMOTIVE INDUSTRY
}

\author{
Gordana Bogdanović ${ }^{\prime}$, Dragan Milosavljević, Aleksandar Radaković, Dragan Čukanović, \\ Vladimir Geroski
}

UDC: 621.01:514.743.4:53.082.55

DOI: $10.24874 / m v m .2017 .43 .03 .05$

\begin{abstract}
Mechanical behaviour of anisotropic media may be seen the best through its behaviour during bulk wave propagation. Such waves may be decomposed into finite plane waves propagating along arbitrary direction $\boldsymbol{n}$ in solid. Properties of these waves are determined by dependence between propagation direction and constitutive properties of media. Three types of such waves may be distinguished in connection to three displacement vectors, which determine acoustic polarization. The most of dynamical systems are naturally nonlinear; here we are going to write Reimann-Christoffel equation. This equation represents propagation condition of bulk waves as set of three homogeneous linear equations. Materials used in present analysis are fibre reinforced with one or two families of continuous fibres. Often used represent of such materials is epoxy resin carbon fibres composite whose material constants are determined with ultrasound methods.
\end{abstract}

KEY WORDS: mechanical behaviour, anisotropic media, shape functions, composite materials, bulk waves

\section{AKUSTIČNI TENZOR I ELASTIČNA PROPAGACIJA TALASA U ANIZOTROPNIM MATERIJALIMA KORIŠĆENIM U AUTOMOBILSKOJ INDUSTRIJI}

REZIME: Mehaničko ponašanje anizotropnih medijuma najbolje se vidi kroz njegovo ponašanje tokom širenja masivnog talasa. Takvi talasi se mogu razgraditi u konačne ravne talase koji će se prostirati duž proizvoljnog $\boldsymbol{n}$ pravca u solidu. Svojstva ovih talasa određena su zavisnošću pravca širenja i konstitutivnih svojstava medijuma. Tri tipa takvih talasa se mogu razlikovati u odnosu na tri vektora pomeranja, koja određuju akustičnu polarizaciju. Većina dinamičkih sistema su prirodno nelinearni; ovde ćemo pisati Reimann-Christoffel jednačinu. Ova jednačina predstavlja uslov propagacije masivnih talasa kao skup tri homogene linearne jednačine. Materijali koji se koriste u sadašnjoj analizi su ojačani vlaknom sa jednom ili dve porodice kontinualnih vlakana. Često korišćeni predstavnik takvih materijala je kompozit vlakno eposkidne smole čije su konstante materijala određena ultražvučnim metodoma.

KLJUČNE REČI: mehaničko ponašanje, anizotropni medijum, funkcija oblika, kompozitni materijali, masivni talasi

${ }^{1}$ Received: June 2017, Accepted August 2017, Available on line December 2017 
Intentationally blank 


\title{
ACOUSTICAL TENSOR AND ELASTIC WAVE PROPAGATION IN ANISOTROPIC MATERIALS USED IN AUTOMOTIVE INDUSTRY
}

\author{
Gordana Bogdanović ${ }^{1}$, Dragan Milosavljevic ${ }^{2}$, Aleksandar Radaković ${ }^{3}$, Dragan \\ $\check{C}$ ukanovic $^{4}$, Vladimir Geroski ${ }^{5}$
}

\section{INTRODUCTION}

New products have been introduced in order to replace materials such as metal and cement. One such material is fibre-reinforced composite, which are have been competing with materials such as steel, aluminium and concrete in cars, aircraft, buildings and everyday sports goods. Materials as these materials due to combining high strength and stiffness with low weight and have many advantages concerning the cost, dimension, surface properties, thermal properties, electric properties, etc. They are also cheaper because they reduce the cost as their maintenance costs are very low, besides a lot of work is being done in order to make them more environmental friendly.

The most important aspect of fibre-reinforced materials is their mechanical behaviour. Constitutive relations has been made by Spencer, for extensible fibres in [1,2] and for inextensible fibres in [3]. These relations are coordinate free, which enabled us to study the material concentrating to the unit vector field tangent to preferred direction, called fibre. Here we are concerned fibre-reinforced composites which have an important property of being anisotropic, and in many cases this anisotropy may be very strong, in the sense that mechanical properties are strongly depend on the direction. The main futures of these materials are the improvement of stiffness and strength, reduction of wear and creep, anisotropic properties, improved strength in fibre direction, high price and complex manufacturing techniques.

In this paper, we consider the propagation of bulk waves in elastic solids reinforced by two families of strong mechanically equivalent fibres.

\section{LOCALIZATION FORM AND ACOUSTIC TENSOR}

Most dynamical systems are naturally non-linear and it is not easy to find closed solution of such systems. In this paper we are mainly interested in illustrating that, mathematically and we consider infinite domains so that we can omit questions concerned with the nature and interpretation of the correct boundary conditions, as well as the appropriate form of the stress tensor and the associated tractions. Equation describing the

\footnotetext{
${ }^{1}$ Gordana Bogdanović, Ph.D., assoc.prof., University of Kragujevac, Faculty of Engineering in Kragujevac, Sestre Janjić 6, 34000 Kragujevac, gocab@kg.ac.rs

${ }^{2}$ Dragan Milosavljević, Ph.D., prof., University of Kragujevac, Faculty of Engineering in Kragujevac, Sestre Janjić 6, 34000 Kragujevac, dmilos@kg.ac.rs

${ }^{3}$ Aleksandar Radaković, Ph.D.,assist. prof., University of Novi Pazar, Vuka Karadžića, bb, 36300 Novi Pazar,Serbia,aradakovic@np.ac.rs

${ }^{4}$ Dragan Čukanović, Ph.D, assist.prof., University of Pristina, Faculty of Technical Sciences in Kosovska Mitrovica, Knjaza Miloša 7,38220 Kosovska Mitrovica,dragan.cukanovic@pr.ac.rs

${ }^{5}$ Vladimir Geroski, Ph.D. student, University of Kragujevac, Faculty of Engineering in Kragujevac, Sestre Janjić 6, 34000 Kragujevac, vlada.geroski@gmail.com
} 
initial weak discontinuity, assuming that tangent stiffness tensor on both sides of the surface of discontinuity, has the same value and the following form

$$
c_{i j k l} n_{j} n_{l} p_{k}=0 \text {, }
$$

where

$$
c_{i j k l}=\frac{\partial W}{\partial e_{i j} \partial e_{k l}},
$$

represents the tangent stiffness tensor, the unit normal to singular surface and represents the polarisation vector. The second order tensor, called the localization tensor is

$$
\Gamma_{i k}=c_{i j k l} n_{j} n_{l} .
$$

This tensor is singular and the polarisation vector is eigenvector associated with the eigenvalue zero, while the classical localization condition in the considered case may be expressed in form

$$
\operatorname{det}\left(\Gamma_{i k}\right)=\left|c_{i j k l} n_{j} n_{l}\right|=0 .
$$

A material model shall be used here for which the localization tensor is nonsingular and, in the analysis of wave propagation, termed as the acoustic tensor, is symmetric and positive definite leading to three positive eigenvalues. The equation of motion may be expressed for infinitesimal displacements $u_{i}$ in the form

$$
\sigma_{i j, j}+f_{i}=\rho \ddot{u}_{i}
$$

If strains are small enough, equations are linear and relation connecting stress and strain are generalized Hooke's Law given as

$$
\sigma_{i j i}=c_{i j k l} e_{k l},
$$

which is postulated by Cauchy. This law is base of linear elasticity. Coefficients are stiffness coefficients. These equations may be solved for the monochromatic wave motion if the harmonic plane wave displacement is expressed as follows

$$
u_{k}=A p_{k} \exp \left(i k\left(n_{r} x_{r}-v t\right)\right) .
$$

In equation (7) is the amplitude factor, while is the unit polarization vector, is the imaginary unit, $\mathrm{k}$ is the wave number, the wave normal and is the phase velocity. Equations (6) and (7) lead to Riemann-Christoffel's equation

$$
\left(c_{i j k l} n_{j} n_{l}-\rho v^{2} \delta_{i k}\right) p_{k}=0 .
$$

Due to the symmetries of the stiffness tensor, the matrix expression in the brackets on the left-hand side is also symmetric. This implies that the three eigenvalues obtained for 
applying the condition for nontrivial solution of the set of homogeneous equations, will be real. The system of homogeneous equations (8) has nontrivial solution provided that

$$
\left|\Gamma_{i k}-\rho v^{2} \delta_{i k}\right|=0,\left|\Lambda_{i k}-v^{2} \delta_{i k}\right|=0, \Lambda_{i k}=\Gamma_{i k} / \rho=c_{i j k l} n_{j} n_{l} / \rho=\lambda_{i j k l} n_{j} n_{l}
$$

Equation (9) in matrix form is

$$
\left|\begin{array}{ccc}
\Lambda_{11}-v^{2} & \Lambda_{12} & \Lambda_{13} \\
\Lambda_{12} & \Lambda_{22}-v^{2} & \Lambda_{23} \\
\Lambda_{13} & \Lambda_{23} & \Lambda_{33}-v^{2}
\end{array}\right|_{=0}
$$

The components of Riemann-Christoffel's tensor may be expressed as

$$
\begin{gathered}
\Gamma_{i l}=c_{i j k l} n_{k} n_{j}=c_{i 11 l} n_{1} n_{1}+\left(c_{i 12 l}+c_{i 21 l}\right) n_{1} n_{2}+\left(c_{i 13 l}+c_{i 31 l}\right) n_{1} n_{3} \\
+c_{i 22 l} n_{2} n_{2}+\left(c_{i 23 l}+c_{i 32 l}\right) n_{1} n_{3}+c_{i 33 l} n_{3} n_{3} .
\end{gathered}
$$

\section{MATERIALS REINFORCED BY ONE FAMILY OF FIBRES}

These materials possess transversal isotropy and, without loss of generality, one may choose one of Cartesian axis, to coincide with fibre direction, for example unit vector of fibre direction may be written as $\left(a_{i}\right)=(1,0,0)$. Such material is usually treated in coordinate system with one axes coincides with axes of transversal isotropy and study constrains on strain energy function from requirements that stay invariant during rotations around that axes. Here we are going to use coordinate free constitutive equations following Spencer [1]. The most general quadratic form of strain energy function, with elastic constants: $\lambda, \mu_{T}, \mu_{L}, \alpha, \beta$, is given as

$$
W=\frac{1}{2} \lambda(\operatorname{tr} \boldsymbol{\varepsilon})^{2}+\mu_{\mathrm{T}} \operatorname{tr} \boldsymbol{\varepsilon}^{2}+\alpha(\boldsymbol{a} \cdot \boldsymbol{\varepsilon} \cdot \boldsymbol{a}) \operatorname{tr} \boldsymbol{\varepsilon}+2\left(\mu_{\mathrm{L}}-\mu_{\mathrm{T}}\right) \boldsymbol{a} \cdot \boldsymbol{\varepsilon}^{2} \cdot \boldsymbol{a}+\frac{1}{2} \beta(\boldsymbol{a} \cdot \boldsymbol{\varepsilon} \cdot \boldsymbol{a})^{2}
$$

Stiffness tensor then may be calculated as follows

$$
\begin{aligned}
& \mathrm{C}_{i j k l}=\frac{\partial^{2} W}{\partial \varepsilon_{i j} \partial \varepsilon_{i j}}=\lambda \delta_{i j} \delta_{k l}+\mu_{\mathrm{T}}\left(\delta_{i k} \delta_{j l}+\delta_{j k} \delta_{i l}\right)+ \\
& \left(\mu_{\mathrm{L}}-\mu_{\mathrm{T}}\right)\left(a_{i} a_{k} \delta_{j l}+a_{i} a_{l} \delta_{j k}+a_{j} a_{k} \delta_{i l}+a_{j} a_{l} \delta_{i k}\right)+ \\
& \alpha\left(a_{k} a_{l} \delta_{i j}+a_{i} a_{j} \delta_{k l}\right)+\beta a_{i} a_{j} a_{k} a_{l} .
\end{aligned}
$$

In expression (13) material constant $\mu_{\mathrm{L}}$ represents shear modulus along the fibre direction $a_{i}, \mu_{T}$ represents shear modulus perpendicular to the fibre direction. Remained material 
constants $\lambda, \alpha, \beta$ may be connected to other modulus such as extension modulus, Yung's modulus or Poisson ratio.

Components of acoustic tensor may be expressed as

$$
\begin{aligned}
& \rho \Lambda_{11}=\left(\lambda+2 \alpha+\beta+4 \mu_{L}-2 \mu_{T}\right) n_{1}^{2}+\mu_{L} n_{2}^{2}+\mu_{L} n_{3}^{2}, \\
& \rho \Lambda_{12}=\left(\lambda+\alpha+\mu_{L}\right) n_{1} n_{2}, \\
& \rho \Lambda_{13}=\left(\lambda+\alpha+\mu_{L}\right) n_{1} n_{3}, \\
& \rho \Lambda_{22}=\mu_{L} n_{1}^{2}+\left(\lambda+2 \mu_{T}\right) n_{2}^{2}+\mu_{T} n_{3}^{2}, \\
& \rho \Lambda_{23}=\left(\lambda+\mu_{T}\right) n_{2} n_{3}, \\
& \rho \Lambda_{33}=\mu_{L} n_{1}^{2}+\mu_{T} n_{2}^{2}+\left(\lambda+2 \mu_{T}\right) n_{3}^{2} .
\end{aligned}
$$

\subsection{Numerical analysis of slowness surfaces when fibres become very strong}

The materials used in the present analysis are fibre reinforced with one family of continuous fibres. Since fibres are much stronger than the matrix, anisotropic properties are emphasized. If a stiffness tensor is defined then, for an arbitrary propagation direction, the phase velocities may be calculated for all three waves, one of which is quasi-longitudinal and the remaining two are quasi-transversal. Their reciprocities represent the points of the corresponding slowness surfaces and for calculating them is useful to define the sagittal plane, presented in Figs. 1. Material constants for such materials, which density is given as $\rho=1,60 \cdot 10^{3} \mathrm{~kg} / \mathrm{m}^{3}$, are measured by ultrasound methods and reported in [4], are

$$
\begin{aligned}
& \lambda=5,65 \cdot 10^{9} \mathrm{Nm}^{-2}, \quad \mu_{T}=2,46 \cdot 10^{9} \mathrm{Nm}^{-2}, \quad \mu_{L}=5,66 \cdot 10^{9} \mathrm{Nm}^{-2}, \\
& \alpha=-1,28 \cdot 10^{9} \mathrm{Nm}^{-2}, \quad \beta=220,90 \cdot 10^{9} \mathrm{Nm}^{-2} .
\end{aligned}
$$

Let us choose Cartesian system whose axes coincide with axes of material symmetries, and we may imagine vertical plane, which coincide initially with coordinate plane and rotate around vertical axis for arbitrary angle. 


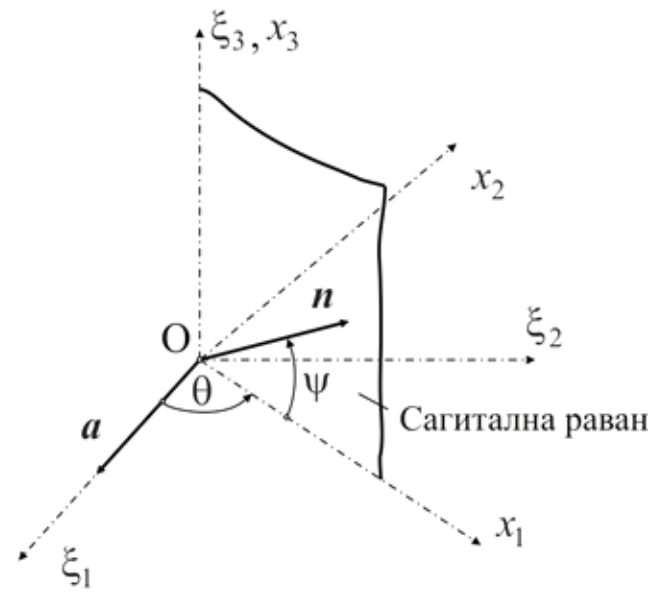

Figure 1. One family of fibres

Taking into account that the material constant given in equation (15), for material reinforced by one family of fibres, slowness surfaces are calculated in program pack MATLAB and presented in Figures 2 and 3.

By varying angle between 0 and $2 \pi$ may be calculated slowness curve in sagittal plane whereas by rotating of sagittal plane around axes for angle slowness surface may be completed. Slowness surfaces, for material reinforced by one family of fibres, are calculated in program pack MATLAB and presented in Figures 2 and 3, for angle. In these figures quasi-longitudinal waves are represented with solid lines, whereas quasi-transversal waves are represented with broken lines.

When fibres become stronger, such a behaviour is more emphasized showing that in the inextensibility case one quasi-shear phase velocity degenerates and may propagate in exceptional directions only. The innermost slowness curve, associated to quasi-longitudinal waves, tends to degenerate to a point, as shown in Figure 3, indicating an infinite phase velocity when the material becomes subject to the inextensibility constraint. The direction of energy propagation, which is normal to the slowness surface, in such cases indicates a singular behaviour of the energy flux vector in a constraint limit. 


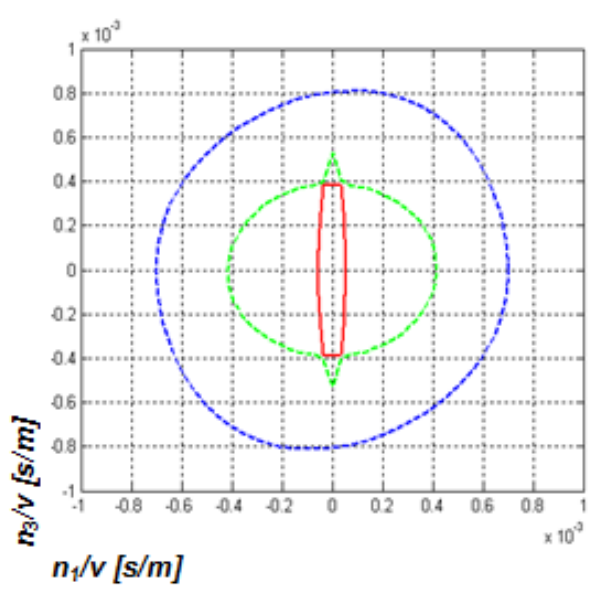

Figure 2. One family of fibres

$\theta=60^{\circ}, \beta=220,29 \cdot 10^{10} \mathrm{~N} / \mathrm{m}^{2}$

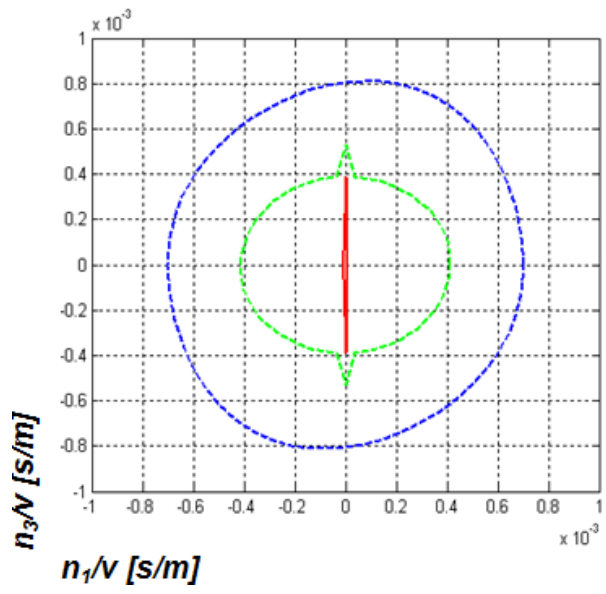

Figure 3. One family of fibres

$\theta=60^{\circ}, \beta=220,29 \cdot 10^{12} \mathrm{~N} / \mathrm{m}^{2}$

\section{CONCLUSIONS}

Mechanics of continuum treats material on macroscopic level in which microscopic level may be used as preparation for homogenization purposes; anisotropy has different effects on wave propagation as well as on complete elastic behaviour of media, which may be observed trough fact, that wave front deviate from spherical shape. About anisotropic material behaviour, general conclusions in mechanical sense are taken from considering of bulk waves propagation.

For considered material acoustic tensor, as propagation condition, has been formed, and determined for different directions of wave propagation. For particular material reinforced by one family of fibres components of that tensor are calculated. These calculations has practical significance, because it has been formed easy mathematical approach which may give fast answer about material behaviour in dynamic circumstances, which often appear in parts of motor vehicles.

This approach may be used as first approximation of dynamical behaviour of real parts with anisotropic characteristics that appears very often in consideration of vehicle construction parts.

\section{ACKNOWLEDGEMENT}

This investigation is a part of the projects TR 33015, TR 32036 and multidisciplinary project III 44007 of Technological Development of the Republic of Serbia. We would like to thank to the Ministry of Education and Science of Republic of Serbia for the financial support during this investigation. 

automotive industry

\section{REFERENCES}

[1] Spencer, A.J.M., Formulation of constitutive equations for anisotropic solids, in Mechanical Behaviour of Anisotropic Solids, J.P. Boehler eds., Amsterdam, 3-26, 1982.

[2] Milosavljević, D., Bogdanović G., Veljović, LJ., Radaković, A., Lazić, M., Failure criteria of fibre reinforced composites in homogenous temperature field, International Journal Thermal Science, Vol. 14 suppl. 285-297.

[3] Nayfeh, A.H., Wave Propagation in Layered anisotropic Media, Book, Elsevier, 1995.

[4] Markham, M., F., Measurement of the Elastic Constant of Fibre Composites by Ultrasonic, Composites, 1, pp. 145-149, 1970.

[5] Bogdanovic, G., Dynamical behaviour of composite laminates, Ph.D. Thesis, Kragujevac, 2011. 